\title{
Reduction in Organic Waste through Recovery from Waste Paper Recycling Mill
}

\author{
Mohammad Nafees, Nazish Huma Khan, Nimra Noor, Sadaf and Farooq Ahmad \\ Department of Environmental Sciences, University of Peshawar, Pakistan. \\ *Corresponding Author Email: nafess36@yahoo.com \\ Received 10 April 2017, Revised 28 November 2017, Accepted 01 December 2017
}

\begin{abstract}
Paper manufacturing industry is characterized by large amount of water consumption and hence high rate of wastewater generation which is concern to water pollution. This study considers the characterization of paper mill effluents for recovery in the form of Total Suspended Solids (TSS) in relation to decrease in organic waste in the form of Biochemical Oxygen Demand $\left(\mathrm{BOD}_{5}\right)$ and Chemical Oxygen Demand (COD). For this purpose sedimentation and coagulation were applied. Coagulation was performed using "Alum" to check its efficiency. The effects of dose rate and settling time of solids were observed for TSS, $\mathrm{BOD}_{5}$ and COD removal. The average concentrations of TDS (860-881 mg/L), TSS (822-836 mg/L), BOD (261-275 mg/L) and COD $(519-550 \mathrm{mg} / \mathrm{L})$ were determined above the permissible limits. By comparing the level of these parameters after sedimentation a visible decrease was observed. TDS, TSS, COD and $\mathrm{BOD}_{5}$ decrease by $19 \%, 37 \%, 17.3 \%$ and $18 \%$, respectively. In coagulation treatment the decrease was $84 \%, 89 \%, 86 \%$ respectively for TSS, COD and $\mathrm{BOD}_{5}$. The study observed maximum recovery in the form TSS $(84 \%)$ along with $\mathrm{BOD}_{5}$ and COD. Therefore, coagulation treatment for paper recycling mill is recommended.
\end{abstract}

Keywords: Coagulation, sedimentation, coagulant, removal efficiency, $\mathrm{BOD}_{5}, \mathrm{COD}$

\section{Introduction}

Paper manufacturing is a water-intensive chemical process are resulting a large amount of wastewater [1]. Demand of paper manufacturing is increasing each year and is more than 300 million tons of wood fiber products. Paper manufacturing is carried out by several techniques such as mechanical, chemical and thermal methods [2]. In these methods the mostly adopted type is mechanical pulping involve grinding of desecrated wooden chips [3]. During paper manufacturing, large quantity of water is required for bleaching and pulping process [4]. As a result same quantity of waste-water is generated and its discharge is a serious problem. These industries are considered as contributors of pollutants to environment in the form of waste-water [5]. The wastewater consists of organic and inorganic matter, COD, BOD 5 , TSS and strong colour along with 300 chlorinated compounds [1-6]. Due to high pollutants content the release of untreated wastewater into receiving water bodies is a major environmental concern [7]. In Pakistan, the annual rate of paper manufacturing is 400,000 tons which generate wastewater @ $36,000 \mathrm{~m}^{3} /$ day [8]. This waste-water is not monitored properly and is discharged into nearby water channels which pose harmful threats to aquatic ecosystem. To reduce the rate of wastewater generation, paper manufacturing industries are strictly forced to adopt zero liquid effluent approaches [9]. Wastewater is generally recycled by paper mill to conserve energy and raw materials while its treatment has been considered important to prevent pollution of aquatic ecosystem [10]. Wastewater from paper recycling mill is biodegradable and can be treated easily [7]. The conventional treatment methods applied for 
wastewater are physical, chemical and biological [11]. Physical treatment includes sedimentation, adsorption, flotation, using physical barriers such as deep bed filters and membranes [12]. Chemical treatment includes coagulation method and has been considered as an important approach for paper mill effluents [13]. Coagulation is a fast treatment method of wastewater in short period of time. It includes salts of strong acids and weak basis such as Alum, ferric chloride, ferrous sulphate etc. as effective coagulants [14]. The advantage of coagulation treatment is the reduction of wastewater pollutants up to lowest level making it cost effective for secondary treatment [15]. While biological treatment is important to remove organic pollutants in wastewater such as trickling filter [12]. Biological treatment is also effective for $\mathrm{COD}$ and $\mathrm{BOD}_{5}$ removal but not efficient in removal of colour and involved high energy consumption [3].

This study is an attempt to analyze paper mill wastewater for recycling and to recover the cellulose content. There are two paper mills working in Hayatabad industrial estate. The paper mills are located with $33^{\circ} 588^{\prime} 51.3^{\prime \prime} \mathrm{N}, 71^{\circ} 25^{\prime} 47.6^{\prime \prime}$ $\mathrm{E}$ and $33^{\circ} 59^{\prime} 46.4^{\prime \prime} \mathrm{N}, 71^{\circ} 25^{\prime} 21.3^{\prime \prime}$ E latitude and longitude respectively. These industries are equipped with machinery to prepare paper from both sources such as wood and paper-waste respectively. In case of non-availability or shortage of raw-wood, the industries recycle paper waste to prepare paper [11]. The paper mills generate large quantities of wastewater which contains higher levels of cellulose content [8]. This wastewater is discharged into industrial drain without any treatment and then finally it joins river Kabul. Such type of untreated wastewater is a threat to aquatic organisms [16]. Therefore, to keep recovering raw materials and keep paper mill environment friendly, arrangements for effluents treatment is considered important for each industry.

\section{Material and Method}

No study has been carried out to check the present status of paper mills at Hayatabad Industrial Estate for paper and water recycling. The wastewater discharged from paper mills is rich in cellulose contents and it is an important rawmaterial used in mold industry for preparation of packing material. To know about the recovery of cellulose and wastewater treatment, paper mills were evaluated. For this purpose, paper mills were visited for processing and interviews were arranged with managers to ask questions about raw material, water consumption, wastewater generation and treatment for recovery of cellulose contents.

\section{Water consumption}

To know about water consumption, the paper mill technical staff members and tube well operators were interviewed.

\section{Sample collection}

Total 8 composite wastewater samples were collected from paper mills. Each composite sample consists of five grab samples collected at one hour interval. The paper mills are discussed here with the names, Paper mill-A and paper millB. Samples were taken in 2-L clean and dried plastic bottles and then brought to laboratory for analysis.

\section{Chemical analysis}

The collected waste-water samples were analyzed for physicochemical parameters $(\mathrm{pH}, \mathrm{EC}$, TDS, TSS, COD and $\mathrm{BOD}_{5}$ ) according to standard methods for the examination of water and wastewater [17]. The $\mathrm{pH}$ and electrical conductivity (EC) were measured using $\mathrm{pH}$ meter and conductivity meter respectively. Both the $\mathrm{pH}$ meter and conductivity meter were calibrated with required buffer solutions to give readings for samples in quickest possible time.

Total Suspended Solids (TSS) and Total Dissolved solids (TDS) were determined by centrifugation method. For suspended solids, $25 \mathrm{ml}$ of wastewater was filtered through a pre-weighted filter paper. The non-filterable material was left on filter paper. This filter paper was then kept in oven at $50^{\circ} \mathrm{C}$ for some time till it become dry. After drying, it was cooled in desiccators and weighted it again. The difference in initial and final weights of filter paper gave the suspended solids. 
The total dissolved solids in wastewater samples were determined by taking $25 \mathrm{ml}$ of sample in a clean pre-weighted china dish. This china dish was kept in oven at $105^{\circ} \mathrm{C}$ for 24 hours. When the sample was completely evaporated the china dish was removed from oven and cooled it in dissector. Then weighted it again. The difference in weight of china dish before and after sample gave the total dissolved solids.

COD was measured by using open reflux method. In this method, water samples were digested with 0.25 standard solution of potassium dichromate in the presence of sulfuric acid. Mercuric sulfate and silver sulfate were used as catalyst. Then sample was titrated with $0.25 \mathrm{~N}$ ferrous ammonium sulfate solution (FAS), using ferroin as indicator. The COD level was determined using equation.

\section{Calculations}

$$
\operatorname{COD}(\mathbf{m g} / \mathrm{L})=\frac{(\mathrm{B}-\mathrm{T}) \mathrm{N} \times 1000 \times 8}{\text { Volume of Sample used }} .
$$

Where

$\mathbf{T}=$ volume of titrant (FAS) used against sample $(\mathrm{ml})$.

$\mathbf{B}=$ Volume of titrant (FAS) used against blank (ml).

$\mathbf{N}=$ Normality of titrant (FAS) $0.25 \mathrm{~N}$.

Equivalent weight of oxygen is 8 .

For $\mathrm{BOD}_{5}, 10 \mathrm{ml}$ of wastewater sample was taken in $300 \mathrm{ml}$ of $\mathrm{BOD}_{5}$ bottle and diluted it till $300 \mathrm{ml}$ with distilled water ( 2 bottles for each sample). Added $1 \mathrm{ml} \mathrm{MnSO}_{4}, 1 \mathrm{ml} \mathrm{KI}$ and allow it to stand for some time to react with oxygen. When the floc settled down, shacked the contents in bottle by turning it upside and down. Added $1 \mathrm{ml}$ of Conc. $\mathrm{H}_{2} \mathrm{SO}_{4}$ just above the surface of bottle and then inverted it carefully to dissolve the floc and added $1 \mathrm{ml}$ of starch indicator. The content of one bottle is transferred into flask and subjected to titration against $\mathrm{Na}_{2} \mathrm{~S}_{3} \mathrm{So}_{4}$ solution. The reading of burette of day-1 was noted as initial $\mathrm{BOD}_{5}$. Bottle2 was kept inside the incubator at $20^{\circ} \mathrm{C}$ for time period of 5 days. After 5 days, the content of bottle-2 was titrated against $\mathrm{Na}_{2} \mathrm{~S}_{3} \mathrm{So}_{4}$ solution until the blue colour disappeared and took the day-5 reading as final reading. The $\mathrm{BOD}_{5}$ was computed from the difference of day- 1 and day- 5 readings using the formula.

\section{Calculations}

$$
\mathrm{BOD}_{5}(\mathrm{mg} / \mathrm{L})=\underline{\mathrm{D}}_{1} \frac{-\mathrm{D}_{2}}{\mathrm{P}}
$$

$\mathbf{D}_{1}=$ day -1 reading

$\mathbf{D}_{2}=$ day -5 reading

$\mathbf{P}=$ volume of sample used

After analysis, results were compared with standards fixed for industrial discharges [18].

\section{Treatment methods}

For $100 \%$ utilization, the paper mill wastewater was treated in the laboratory. The effluent was subjected to two stage treatment, i) sedimentation and ii) coagulation as discussed below:

\section{Physical treatment (Sedimentation)}

First, sedimentation treatment was carried out. In this treatment, 1 liter of each wastewater sample was taken in a graduated cylinder and allowed to stand for $24 \mathrm{hrs}$ without adding any chemical. When the settable particles settled down then each sample was analyzed to find its characteristics.

\section{Chemical treatment (Coagulation)}

Coagulation method was applied for TSS removal. In coagulation, Alum $\left(\mathrm{Al}_{2}\left(\mathrm{SO}_{4}\right)_{3} 18 \mathrm{H}_{2} \mathrm{O}\right)$ was used as a coagulant. Alum is one of the raw materials used by paper mill therefore its selection was preferred for treatment of wastewater. For this purpose, $1000 \mathrm{mg} / \mathrm{L}$ stock solution was prepared. One $\mathrm{mL}$ of this solution when added to 1 liter sample, was equivalent to $1 \mathrm{mg} / \mathrm{L}$ concentration of the coagulant. The sample was subjected to JarTest by adding different doses of Alum in combination with alkalinity with a ratio of $2: 1$ respectively. The Jar apparatus was consisted of three cylinders with capacity of 1 liter each. Samples were shacked well for a minute and then transferred into Jar-Test apparatus. The effect of adding 5 to $50 \mathrm{mg} / \mathrm{L}$ of coagulant (Alum) was tested. Settling time and coagulant dosage was investigated for removal efficiency of suspended solids. The efficiency of TSS removal was determined in percentage. 
As Alum is acidic in nature and affects the coagulation process negatively. Therefore $\mathrm{pH}$ was kept above 7 with the help of $\mathrm{Na}_{2} \mathrm{CO}_{3} @$ of 0.5 $\mathrm{mg} / \mathrm{L}$ for each $1 \mathrm{mg} / \mathrm{L}$ of Alum [21]. In coagulation treatment, $\mathrm{pH}$ was monitored properly for better performance [3].

\section{Percentage reduction of pollutants}

The percent removal of pollutants, TSS, TDS, $\mathrm{BOD}_{5}$, and COD was determined using equation.

Percentage Reduction $=\underline{\mathrm{C}}_{1} \frac{-\mathrm{C}_{2}}{\mathrm{C}_{1}} \times 100$

$\mathrm{C}_{1}$ refers initial value of pollutant and $\mathrm{C}_{2}$ refers final value of pollutant [22].

\section{Results and Discussions}

The paper mills use ground water with daily consumption of $2176 \mathrm{~m}^{3}$ and $2614 \mathrm{~m}^{3}$ to prepare 12-15 tons paper/day. The mills use $72000 \mathrm{~L}$ water per ton. The daily wastewater discharge was 1936.4 and $2489.5 \mathrm{~m}^{3}$ by paper mill$\mathrm{A}$ and $\mathrm{B}$ respectively. A fraction of this wastewater is recycled in processing but at the end, the water is not recycled and is directly discharged into outside nullah/drain. Studies conducted in 2010 revealed that this wastewater is a continuous source of threat for receiving water body, the Kabul River. It also contaminates the drinking water quality of the nearby areas [11-16].

\section{Analytical results of untreated wastewater}

Among water parameters, EC is not defined by Pak-NEQS and was measured as an indicator for treatment. The $\mathrm{pH}$ of paper mill effluents ranged between 8.2 and 8.3. The average values of electrical conductivity were 1638 and $1764 \mathrm{uS} / \mathrm{cm}$. Higher value of EC in paper mill effluents is due to the presence of dissolved salts [23]. TDS was observed within the permissible limit in effluents of both paper mills (860-881 $\mathrm{mg} / \mathrm{L})$. However, high concentration of TDS increases the chances of turbidity and reduces the solubility of gases such as oxygen [23]. TSS, $\mathrm{BOD}_{5}$ and COD were found above the permissible limits (Table-1). Literature revealed that discharged effluents of paper mill contain different chemicals. Therefore, paper mill is associated with pollution problems including high TDS, TSS, $\mathrm{BOD}_{5}, \mathrm{COD}$ etc. [24].

\section{Paper mill Waste-water after sedimentation treatment}

As a result of primary sedimentation, $\mathrm{pH}$ was observed with average range of 7.1 and 7.3 in both the paper mills. The average values of EC were $1426 \mu \mathrm{S} / \mathrm{cm}$ to $1483 \mu \mathrm{S} / \mathrm{cm}$. The application of sedimentation treatment, TDS was reduced up to $15 \%$ to $19 \%$. TSS contents were measured in the average range of $537 \mathrm{mg} / \mathrm{L}$ to $554 \mathrm{mg} / \mathrm{L}$. About 34$37 \%$ suspended solids were removed under sedimentation (Table-2). Thompson et al, (2001) reported that sedimentation is an important and effective pre-treatment for removal of TSS from paper mill effluents [25]. Primary sedimentation has removed $\mathrm{BOD}_{5}$ to some extent. $\mathrm{BOD}_{5}$ was reduced from $12 \%$ to $18 \%$ for paper mill $\mathrm{A}$ and $\mathrm{B}$ respectively. Final results were above the limit defined in Pak-NEQS [18]. Impact of primary sedimentation was also observed for removal of COD. The level of COD was reduced to $12 \%$ and $18 \%$ for both paper mills (Table-2).

\section{Paper mill wastewater after coagulation}

As mentioned earlier, $\mathrm{pH}$ was adjusted above 7.5 by adding alkalinity and was kept within the permissible limits defined in Pak-NEQS [18]. Electrical conductivity was determined with average range of 1511-1562 $\mu \mathrm{S} / \mathrm{cm}$. In coagulation process, EC values increased due to addition of Alum and alkalinity.

The concentrations of TDS were observed increased in treated samples. The increase was due to addition of coagulants and alkalinity. The average contents of removable suspended solids after coagulation ranged between 135 and 141 $\mathrm{mg} / \mathrm{L}$. The removal rate of suspended solids was calculated 83 and $84 \%$ respectively. The level of $\mathrm{BOD}_{5}$ was reduced to 36 and $38.5 \mathrm{mg} / \mathrm{L}$ with the average percent efficiency of $86 \%$ (Table-3). A decreasing trend in settling time was observed with increase in dosage of coagulant. It is due to the 
decline of colloidal particles by neutralizing the forces that keep colloidal near to each other. Literature revealed that in coagulation process, small particles got combine to form macro molecules in the form of floc which settles down due increase in weight [3].

The content of COD in collected wastewater samples was reduced to 57 and 77 mg/L (86-89\%) [26]. Dilek and Gokcay (1994) reported that Alum is one of the best coagulants for COD removal. While Stephenson and Duff (1996) recommended Alum as one of effective coagulant for wastewater treatment [27]. Under coagulation treatment, the maximum removal of $\mathrm{BOD}_{5}$ was calculated as $86 \%$ and COD was $89 \%$ respectively (Table-3). Pokhrel and Viraraghavan (2004) suggested coagulation method for treatment of paper mill effluents and strongly encouraged it for removal of $\mathrm{BOD}_{5}[2]$.

\section{Table- 1 Results of Untreated Paper Mill Wastewater}

\begin{tabular}{|c|c|c|c|c|c|c|c|c|c|}
\hline \multicolumn{5}{|c|}{ Paper Mill-A } & \multicolumn{4}{|c|}{ Paper Mill-B } & \multirow{2}{*}{ Pak-NEQS } \\
\hline Parameter & Min & $\operatorname{Max}$ & Avg & S.D & Min & $\operatorname{Max}$ & Avg & S.D & \\
\hline $\mathrm{pH}$ & 7.8 & 8.5 & 8.2 & 0.44 & 7.9 & 8.6 & 8.3 & 0.44 & $06-10$ \\
\hline $\mathrm{EC} \mu \mathrm{S} / \mathrm{Cm}$ & 1689 & 1754 & 1738 & 11.21 & 1725 & 1824 & 1764 & 11.5 & -- \\
\hline TDS mg/L & 846 & 878 & 860 & 8.26 & 862 & 915 & 881 & 7.33 & 3500 \\
\hline TSS mg/L & 814 & 867 & 836 & 7.41 & 805 & 844 & 822 & 7.2 & 150 \\
\hline COD mg/L & 540 & 620 & 550 & 4.68 & 511 & 609 & 519 & 4.23 & 150 \\
\hline $\mathrm{BOD}_{5} \mathrm{mg} / \mathrm{L}$ & 267 & 306 & 275 & 2.61 & 270 & 297 & 261 & 2.4 & 80 \\
\hline
\end{tabular}

Table-2. Characteristics of Paper Mill Effluents after Sedimentation

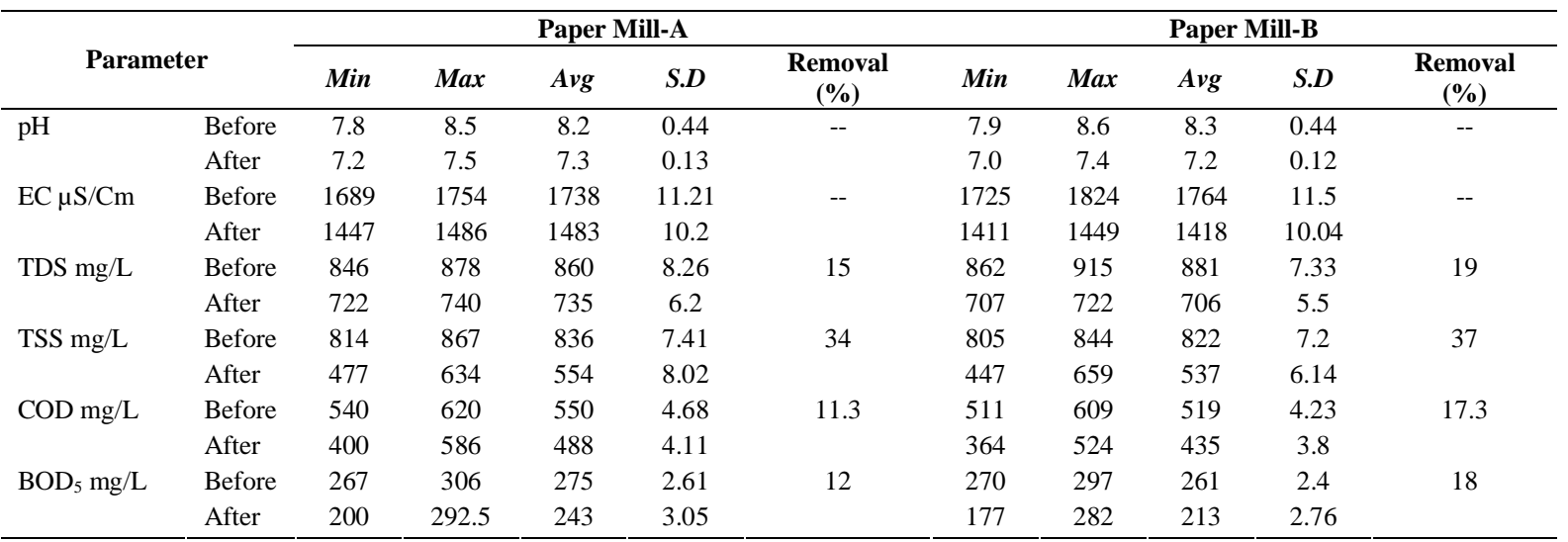

Table-3. Characteristics of Paper Mill Effluents after Coagulation

\begin{tabular}{|c|c|c|c|c|c|c|c|c|c|c|c|}
\hline \multicolumn{7}{|c|}{ Paper Mill-A } & \multicolumn{5}{|c|}{ Paper Mill-B } \\
\hline Parameter & & Min & $\operatorname{Max}$ & Avg & $S . D$ & $\begin{array}{c}\text { Removal } \\
(\%)\end{array}$ & Min & $\operatorname{Max}$ & Avg & $S . D$ & $\begin{array}{c}\text { Removal } \\
(\%)\end{array}$ \\
\hline \multirow[t]{2}{*}{$\mathrm{pH}$} & Before & 7.8 & 8.5 & 8.2 & 0.44 & -- & 7.9 & 8.6 & 8.3 & 0.44 & -- \\
\hline & After & 8.1 & 8.6 & 8.3 & 0.31 & & 8.1 & 8.4 & 8.2 & 0.26 & \\
\hline \multirow[t]{2}{*}{$\mathrm{EC} \mathrm{uS/Cm}$} & Before & 1689 & 1754 & 1738 & 11.21 & -- & 1725 & 1824 & 1764 & 11.5 & -- \\
\hline & After & 1741 & 1778 & 1762 & 8.22 & & 1702 & 1722 & 1711 & 9.13 & \\
\hline \multirow[t]{2}{*}{ TDS mg/L } & Before & 846 & 878 & 860 & 4.26 & -- & 862 & 915 & 881 & 4.33 & -- \\
\hline & After & 868 & 885 & 879 & 4.21 & & 847 & 860 & 854 & 4.03 & \\
\hline \multirow[t]{2}{*}{ TSS mg/L } & Before & 814 & 867 & 836 & 7.41 & 84 & 805 & 844 & 822 & 7.2 & 83 \\
\hline & After & 120 & 148 & 135 & 2.52 & & 126 & 157 & 141 & 2.13 & \\
\hline \multirow[t]{2}{*}{ COD mg/L } & Before & 540 & 620 & 550 & 4.68 & 86 & 511 & 609 & 519 & 4.23 & 89 \\
\hline & After & 34 & 133 & 77 & 1.1 & & 36 & 98 & 57 & 1.2 & \\
\hline \multirow[t]{2}{*}{$\mathrm{BOD}_{5} \mathrm{mg} / \mathrm{L}$} & Before & 267 & 306 & 275 & 2.61 & 86 & 270 & 297 & 261 & 2.4 & 86 \\
\hline & After & 17 & 67 & 38.5 & 1.2 & & 20 & 49 & 36 & 1.03 & \\
\hline
\end{tabular}




\section{Removal of suspended solids with coagulation}

In coagulation process, the minimum removal of suspended solids was observed $20 \%$ for a combination of 5:3 of Alum and alkalinity. The addition of $30 \mathrm{mg} / \mathrm{L}$ Alum and $25 \mathrm{mg} / \mathrm{L}$ of alkalinity, decrease in suspended solids was observed by $68 \%$. The removal efficiency was further increased to $76 \%$ by adding $40 \mathrm{mg} / \mathrm{L}$ Alum and $20 \mathrm{mg} / \mathrm{L}$ of alkalinity. Maximum TSS removal (84\%) was possible with $50 \mathrm{mg} / \mathrm{L}$ Alum and 25 $\mathrm{mg} / \mathrm{L}$ of alkalinity (Fig.1). In comparison to sedimentation process, coagulation showed more effectual results in pollution reduction. Therefore coagulation can be considered as a good treatment for recovery of cellulose contents. Literature revealed that increase dosage of coagulant case the decrease in confederations of suspended solids and hence effects to increase its percent removal [2829].
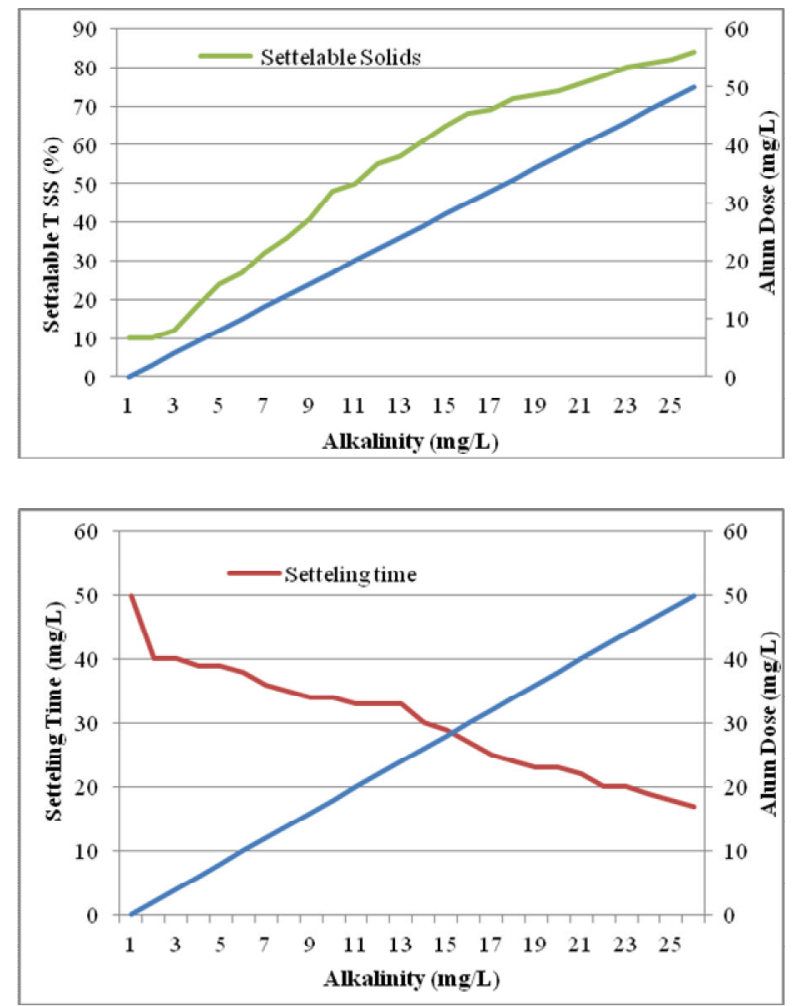

Figure 1. Effect of Coagulation on Settleable Solids

\section{Settling time}

During coagulation process, visible decrease was observed in settling time along with the removal of suspended solids. The settling time during sedimentation was 24 hours. During coagulation, the combination of 30,40 and $50 \mathrm{ml}$ of Alum with 15, 20 and $25 \mathrm{ml}$ of alkalinity, the time observed for these combinations was 27,22 and 17 minutes respectively (Fig.1). The settling time was dependent upon coagulant and alum doses.

\section{Conclusion}

The recovery of TSS from paper mill based on waste-paper is possible through simple sedimentation and coagulation. This will not only economize the waste paper recycling process, but will reduced pollution load in term of TSS, $\mathrm{BOD}_{5}$ and COD. To keep the mill environment friendly, treatment of wastewater by coagulation treatment is suggested.

\section{Acknowledgment}

Authors are thankful to the honorable Managers and Plants Incharge of visited industries for their assistance in providing relevant data. We are also thankful to the Centeral Resource laboratory, Department of Physics, University of Peshawar for their kind help in chemical analysis.

\section{References}

1. P. K. Chaudhari, B. Majumdar, R. Choudhary, D. K. Yadav and S. Chand, Environ. Technol., $31 \quad$ (2010) 363. https://doi.org/10.1080/0959333090348666 $\underline{5}$

2. D. Pokhrel and T. Viraraghavan, Sci. Total Environ., 333 (2004) 58. https://doi.org/10.1016/j.scitotenv.2004.05. $\underline{017}$

3. P. Kumar, T. T. Teng, S. Chand and K. L. Wasewar, Int. J. Chem. Mol. Nucl. Mater. Metall. Engi., 5 (2011) 720. scholar.waset.org/1307-6892/13277

4. A. Y. Zahrim, Melissa, L. Gilbert and J. Janaun, J. Appl. Sci., 7 (2007) 2167. http://www.docsdrive.com/pdfs/ansinet/jas/2 007/2164-2167.pdf

5. G. Kovacs, S. Zucker and T. Maze, Astron \& Astrophysics, 391 (2002) 377. 
https://doi.org/10.1051/0004-

6361:20020802

6. M. C. Monte, E. Fuente, A. Blanco and C. Negro, Waste Manag., 29 (2009) 308. https://doi.org/10.1016/j.wasman.2008.02. $\underline{002}$

7. A. Ali, H. N. Hashmi and N. Baig, Int. J. Eng., 3 (2013) 340.

http://annals.fih.upt.ro/pdffull/2013/ANNALS-2013-3-56.pdf

8. Arshad Ullah, J. Emerg. Trends Appl. Eng., 1 (2016) 24.

9. W. K. Lafi, in: Recent Researches in Energy, Environ, Devices, Systems, Communi and Computers, (S. Chen, N. Mastorakis, F. Rivas-Echverria, V. Mladenov, Eds) WSEAS Press, Italy (2011) 61-69.

10. M. Irfan, T. Butt, N. Imtiaz, N. Abbas, R. A. Khan and A. Shafique, Arab. J. Chem., (2013) https://doi.org/10.1016/j.arabjc.2013.08.007

11. M. Nafees, W. Shah, H. Khan and Zahidullah, J. Sci. Technol., 34 (2010) 36.

12. A. Vishnushama and Ambikapathi, Improvement of Alum \& PACL coagulants for the treatment of pulp and paper mill wastewater. BS thesis submitted to Chemical and Natural Resources Engineering, University Malaysia Pahang, (2010) http://umpir.ump.edu.my/3820/1/CD5966_A Vishnushama.pdf

13. Y. Bennania, K. Kssuti, E. Drazevi and M. Rozi, Environ Technol., 4 (2011) 8. http://dx.doi.org/10.1080/09593330.2011.61 $\underline{0828}$

14. F. B. Dilek and S. Bese, Water SA, 27 (2001) 366.

https://doi.org/10.4314/wsa.v27i3.4980

15. A. M. Deegan, B. Shaik, K. Nolan, K. Urell, M. Oelgemoller, J. Tobin and A. Morrisey, Int. J. Environ. Sci. Technol., 8 (2011) 666. https://doi.org/10.1007/BF03326250

16. F.A. Jan, M. Ishaq, I. Ihsanullahb and S. M. Asim, J. Hazard. Mater., 176 (2010) 616. https://doi.org/10.1016/j.jhazmat.2009.11.0 $\underline{73}$

17. American Public Health Association (APHA). Standard Methods for the
Examination of Water and Wastewater, 21 (2005) 259. doi: 10.4236/aim.2016.611081

18. National Environmental Quality Standards (NEQS). Gazette of Govt. of Pakistan, (1993).

19. H. S. Peavy, D. R. Rowe and G. Techobangolous, Environmental Engineering. Mc-Graw Hill Book Company, New York, (1985) 137.

https://trove.nla.gov.au/version/170124212

$20 . \quad$ A. A. Tatsi, A.I. Zouboulis, K. A. Matis and P. Samaras, Chemosphere, 53 (2003) 744. https://doi.org/10.1016/S00456535(03)00513-7

21. H. S. Peavy, D. R. Rowe and G. Techobangolous, Environmental Engineering. Mc-Graw Hill Education (India) Private Limited, New Dehli, (2015) 140. https://www.abebooks.com/booksearch/isbn/0070491348/

22. D. Sivakumar and J. Nouri, Global $J$. Environ. Sci. Manage., 1 (2015) 304. doi: https://doi.org/10.7508/gjesm.2015.04.0 $\underline{04}$

23. F. K. Bangash and S. Alam, J. Chem. Soc. Pak., 28 (2006) 278. http://www.jcsp.org.pk/ArticleUpload/11144950-1-CE.pdf

24. K. Hossain and N. Ismail, Res. J. Environ. Toxicol., 9 (2015) 134. doi: 10.15171/ijb.1216

25. G. Thompson, J. Swain, M. Kay and C. F. Forster, Bioresour. Technol., 77 (2001) 286. https://doi.org/10.1016/S09608524(00)00060-2

26. F. B. Dilek, C. F. Gokcay, Water Sci. Technol., 29 (1994) 161. http://wst.iwaponline.com/content/29/9/161

27. R. J. Stephenson and S. J. B. Duff, Water Res., 30 (1996) 792.

https://doi.org/10.1016/00431354(95)00213-8

28. S. Mohammad, W. Lafi, K. Bani-Melhem, F. Gharagheer and O. Dhaimat, Sep. Sci. Technol., 47 (2012) 708. https://doi.org/10.1080/01496395.2011.634474

29. S. Marjana and D. Vnucec, Cent. Eur. J. Chem., 10 (2012) 136. doi: 10.2478/s11532-011-0121-8 